\title{
Principles of Document Design ${ }^{1}$
}

\author{
Ricky Telg and Ashley McLeod-Morin²
}

This publication on the principles of document design is the second of a five-part series on document design. This series also covers the document design process, elements of document design, graphic file formats, and brochure and newsletter design.

\section{Introduction}

Good design does not call attention to itself, but good designers use the principles of document design to make sure their layouts look pleasing and attractive. This publication, created for anyone with an interest in designing effective documents, covers the principles of document design: balance, proportion, order, contrast, similarity, and unity.

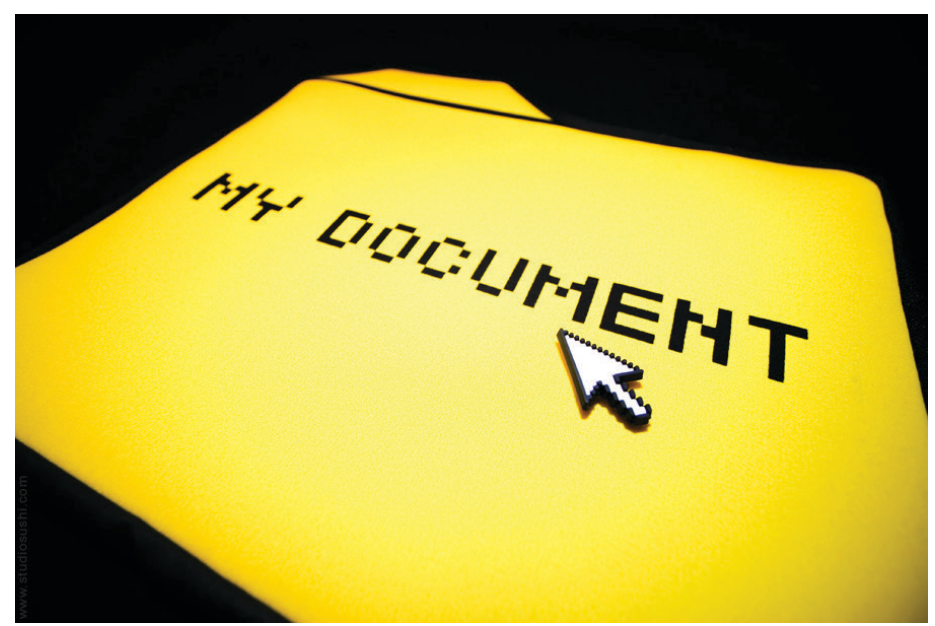

Figure 1. My Document.

Credits: Design by James Cao, StudioSushi ${ }^{\mathrm{TM}}$ CC BY-NC-SA 2.0

\section{Balance}

Balance involves imagining a line dividing a page either vertically or horizontally and then placing visual elements so they are either symmetrically (formally) balanced or asymmetrically (informally) balanced.

Symmetrical balance, or formal balance, is mirror-image balance. It occurs when all the visual elements on one side of the page are mirrored on the other side. The visual elements may not be identical objects, but they are similar in terms of numbers of objects, colors, and other elements. The primary value to readers when you use formal balance is that the reader does not have to work hard to see relationships between message elements. A document that has formal balance presents stability, security, authority, and thoughtfulness. However, it also may be seen as unexciting and unimaginative.

Asymmetrical balance, or informal balance, occurs when several smaller items on one side of the imaginary line are balanced by a large item on the other side, or smaller items are placed further away from the center of the screen than larger items. Most document design is done using asymmetrical balance. Asymmetrical balance is generally seen as being more interesting and exciting. A message using asymmetrical balance is seen as dynamic, fresh, inviting, creative, and friendly.

When you balance elements asymmetrically, you use their visual weight to create an arrangement that is pleasing

1. This document is WC128, one of a series of the Department of Agricultural Education and Communication, UF/IFAS Extension. Original publication date June 2012. Revised April 2021. Visit the EDIS website at https://edis.ifas.ufl.edu for the currently supported version of this publication.

2. Ricky Telg, professor, Agricultural Communication, Department of Agricultural Education and Communication; and Ashley McLeod-Morin, media coordinator, UF/IFAS Center for Public Issues Education in Agriculture and Natural Resources; UF/IFAS Extension, Gainesville, FL 32611.

The Institute of Food and Agricultural Sciences (IFAS) is an Equal Opportunity Institution authorized to provide research, educational information and other services

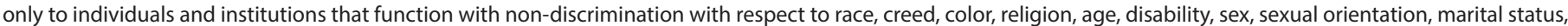
national origin, political opinions or affiliations. For more information on obtaining other UF/IFAS Extension publications, contact your county's UF/IFAS Extension office. U.S. Department of Agriculture, UF/IFAS Extension Service, University of Florida, IFAS, Florida A \& M University Cooperative Extension Program, and Boards of County Commissioners Cooperating. Nick T. Place, dean for UF/IFAS Extension. 
to the eye. Visual weight is the amount of "weight" or prominence an image has. The eye is more attracted to a space with heavy visual weight because of its dominance. For example, a small, dark visual may have as much, or more, visual weight than a larger one with lighter tones. Black is heavier than white. Intense colors are heavier than those that have been toned down. Visual elements such as illustrations, photos, and headlines-by their size-carry more weight than text. One darker item may need to be balanced by several lighter items. You achieve a balanced look by spacing these elements with careful consideration of their relationship with everything else on the document.

\section{Proportion}

Proportion is the spatial relationship between each design element. The eye visually compares the relationship of each element's area, size, weight, and location to all of the others on the page. You can create pleasing visual proportion by dividing your page into thirds. The middle section then would likely be a good place to put your most important visual element, and it should be in proportion to the rest of the page. The natural center is slightly above the exact center of the page. The natural center is the most common focal point when viewing a document. That is why for most newspapers, the major story's headline/photograph is immediately above the fold in the newspaper. Another term to know is the message zone, which is the entire page, containing all elements of your message: text, visuals, and graphics.

\section{Order}

Order is how you show sequence and importance. Order refers to most readers' assumption that what they see first on a page is more important than what they see later on. Studies have shown that on a printed page the most important information is best positioned at the top, followed by information of decreasing importance as the reader moves down the page. You can see that concept on any newspaper page. The important information is at the top to catch readers' attention. For brochures, major headings are at the top, followed by less-important but related information.

\section{Contrast}

Contrast refers to the dominant focus or element on a page. Use contrast to show difference and to create emphasis. For example, darker and larger visual elements stand out on your page. They are considered more interesting and are the focus of your document design.
All good designs should have a focal point that stands out on the page. Readers assume that a difference in appearance means a difference in function or meaning. Contrast is a valuable tool to draw attention to such things on a page as warning labels, cautions, and notes. Contrast can also apply to the following visual elements:

Shape-This could mean using a typeface for text that you want to stand out from text using another typeface, or using a recognizable symbol, such as a stop sign or a warning triangle.

Size-To draw emphasis to an area on your document, you may want to use text that is a larger size than the surrounding text.

Color-Any use of color, in an otherwise black-and-white document, will draw readers' attention.

Value-This refers to creating a visual element that has a higher value than the surrounding objects. This can be done by bolding text or adding a gray box behind the text.

\section{Similarity}

Where contrast focuses on dominance or emphasis, similarity shows that design elements are alike. When people see things that look similar, they assume they have similar functions. Visual elements could show similarity in the following ways:

Shape-All of the text for a specific function would be placed in the same typeface. This is common in newsletters, where headlines are in one typeface, and the text for a story is in another typeface.

Size-All of the text for a specific function would be in the same size. Again, in most newsletters, headline text is a larger size than the text used in the stories. The story text, for all stories, is always the same.

Color-All of the colors-red, for example-would be in the same hue.

Value-Bullet-pointed text would have the same relative value.

\section{Unity}

Unity deals with how all of a message's elements tie together visually. A message with good unity is one where all of its visual elements complement each other. The pages in the document should hold a reader's attention, but they 
should be simple to follow. Each page also should have a similar structure so that they are consistent-or unifiedthroughout. Letting each page have its own shape and form is not the right way to design a document.

\section{Additional Information}

Diggs-Brown, B., \& Glou, J. (2004). The PR styleguide: Formats for public relations practice. Belmont, CA: Wadsworth.

Kimball, M. A., \& Hawkins, A. R. (2008) Document design: A guide for technical communicators. Boston, MA: Bedford/ St. Martin's.

Marsh, C., Guth, D. W., \& Short, B. P. (2005). Strategic

writing: Multimedia writing for public relations, advertising, sales and marketing. Boston, MA: Pearson Education.

Telg, R. \& Irani, T. A. (2012). Agricultural communications in action: A hands-on approach. Clifton Park, NY: Delmar. 